\title{
An Examination of the Relationship between the Social Appearance Anxiety and Conscious Awareness
}

\author{
Ali Haydar Şar \\ Department of Guidance and Psychological Counselling, Faculty of Education, Sakarya University, Turkey
}

Copyright $\bigcirc 2018$ by authors, all rights reserved. Authors agree that this article remains permanently open access under the terms of the Creative Commons Attribution License 4.0 International License

\begin{abstract}
This research examines the relationship between social appearance anxiety and conscious awareness level of university students based on descriptive type relational screening in terms of various variables. The sample of the research is composed of 295 university students studying at Ağrı İbrahim Çeçen University. The data were collected via The Personal Information Form which was developed by researchers (KBF), Conscious Awarness Questionnaire, and the Social Appearance Anxiety Scale (SSI). The obtained data were analyzed by using Statistical Package for the Social Sciences package program. According to the findings, there is no statistically significant difference between gender and social appearance anxiety, and conscious awareness levels of the university students. In addition to this, it was found that there is no significant difference between the class level of the participants and social appearance anxiety, and conscious awareness levels of the university students. Finally, the results show that there is a significant difference between age and the Conscious Awareness variable, and the averages of the social appearance anxiety, and conscious awareness levels of the participants.
\end{abstract}

Keywords Social Appearance Anxiety, Conscious Awareness, Awareness

\section{Introduction}

Individuals have a tendency to provide satisfaction by understanding the society they were born into and by solving their needs to adapt by learning. A condition of providing individuals internal gratification depends on the process of adapting to their social environment and the condition of receiving sufficient-positive feedback. The process of learning and adapting to the social environment of the individual is called socialization. As a part of being an important part of the personality structures of the individuals in the socialization process, their appearance also has an important place. It has been determined that external research influences the social status and perception of the individual $[1,2]$.

The fact that external appearance becomes an important factor in the socialization of individuals leads them to attach more importance to the external appearances of the individuals, so; this situation triggers the of social appearance anxiety in the individuals [3, 2].

Anxiety about social appearance can be defined as the fear of negative evaluation of the individual who appears in the community [4]. Social appearance anxiety, a variation of social anxiety, is defined as the anxiety and tension experienced by individuals when their external appearance is assessed by other individuals [5]. Social appearance anxiety, social anxiety level and negative body image perception have a significant positive relationship with the level of perception [6]. Again, according to a similar view, the low body image perceptions that individuals' possess have the tendency to avoid the individuals from the social environment, which in turn affects the level of social anxiety negatively [7].

It can be thought that social anxiety can give an idea about the prevalence of social anxiety which investigated on the previous studies considered as a derivative of social anxiety. The prevalence of social anxiety ranges from $6,7 \%$ to $10,7 \%[10,11]$, which suggests that there are serious research outcomes related to the prevalence of social anxiety. In addition, considering the fact that the relationship between usage rates of social networking and social anxiety is positive [8] and that there is a serious increase in social networking usage [9] visible. In recent years, it has been seen that the importance of therapeutic work has been emphasized in relation to social appearance anxiety, which is thought to be increasing day by day. Conscious awareness approaches take an important place in these studies.

Awareness-based work in the last decade has shown that individuals significantly reduce their anxiety levels. Awareness means that the individual is aware of his own thinking processes and can control these processes $[10,11]$. Awareness focuses on the instant by accepting the inner 
practice of the inner workings by making mental and bodily practices from the meditations practiced in the Eastern geography of the basic practice [12]. According to another definition, awareness is directed at attention, voluntarily and without trial, towards the flow of instant experiences [13]. The concept of awareness associated with consciousness states that therapeutic change is one of the important and latent stages [14]. The conscious awareness that is based on Buddhism is defined as the focal point of the present moment without any judgment [15]. Conscious awareness is the process of clarifying and interpreting the changes in the environment when we are subjected to intense incentive bombardment [16]. Conscious awareness-oriented studies have shown that the development of awareness is positively associated with physical and emotional well-being, while the negative association with depression and anxiety is seen $[15,17,18]$. According to another study with parallel findings, instant focused on the attention shows that individual has different qualities from negative self-focused styles $[15,17]$.

Studies based on faculty have contributed positively to the subjective well-being of individuals $[15,17]$, negative relationship with anxiety levels [19] and studies need for a closer examination of the relationship between conscious awareness and social appearance anxiety. This study was carried out in order to provide data accumulation related to the relationship between social appearance anxiety and conscious awareness as a result of this need and literature review.

\subsection{Purpose of the Study}

As a result of the literature survey, there was no study investigating the relationship between Social Appearance Anxiety and Conscious Awareness. In this study, it is aimed to find answers to the questions mentioned below, to eliminate the lack of data in the literature and provide data accumulation related to the social appearance anxiety concern which is a derivative of anxiety problem, one of the main fields of study of psychology.

\subsection{Problem Statement}

This research examines the relationship between levels of social appearance anxiety and conscious awareness of university students; which has been carried out with descriptive type relational scanning model in terms of various variables. In selecting the universe and sample, it has been noted that sample size and characteristics of the individuals forming the sample are generalizable. It is important that the number of samples is taken care of to make up $20 \%$ of the universe in relational screening studies and that the individual variables of the individuals forming the sample are generalizable [20].

The following hypothetical responses will be sought within the scope of the research with the hypothetical movement indicated.

- Does the level of Conscious Awareness and Social Appearance Anxiety differ according to the individual variables of the participants?

- Is there a meaningful relationship between participants Social Appearance Anxiety and Conscious Awareness levels?

\section{Method}

\subsection{Participants}

The sample of the research consists of 295 participants, 186 of the participants are female and 109 of male studying at Agri İbrahim Çeçen University. Considering the distribution of parents according to their relationship status which is among the research variables, while the parents of 81 participants are living separately, 214 participants' parents are living together. On the other hand, 106 participants are involved in the age range of 18-20, 102 of them are in 20-22, 58 of them are in 22-24, and finally 29 of them are in the age range of 24-26. According to the class level distribution, it is seen that there are 64 participants in the first grade, 156 of them in second grade, 44 of them are in the third grade, and finally 31 of the participants involved in the fourth grade.

\subsection{Instruments}

\section{Conscious Awareness Scale (C.A.S)}

Factor analysis of the scale as a result of exploratory and confirmatory factor analysis studies was done to test the validity of the scale, It has been adapted by Özgür, Arslan, Kesici and Deniz developed by Brown and Ryan [15]. The total change explained by the five eigenvalues is 58.02 . The first sudden change in the eigenvalue graph emerged in the first factor. The first factor was $4.24(28.33 \%)$, the second factor was $1.22(8.18 \%)$, the third factor was 1.13 $(7.54 \%)$, the fourth factor was $1.08(6.73 \%)$ and the fifth factor was $1.01(6.16 \%)$. Internal consistency coefficient of your scale $\alpha=.82$. The item-total correlations obtained from the scale ranged from .43 to .68 . Six point scale Likert and one-dimensional scale consist of 15 items.

\section{Social Appearance Anxiety Scale (SAAC)}

The Social Appearance Anxiety Scale (SAAC) developed by Hart et al. [5] and then validated by Turkish Dogan [21] was a Likert type with 5 items and consisted of 16 items. Cronbach Alpha internal consistency coefficient for SSI was .93 , test-retest reliability coefficient was .85 and reliability coefficient was .88 . The result is that the item-total correlation coefficients are between .32 and .82 . 


\subsection{Data Analysis}

In the research, Shapiro-Wilk test was applied to test the hypothesis of normality, which is the precondition of parametric tests, and the skewness coefficients are looked and the results are not between +1 and -1 which is acceptable [22]. Therefore, the use of nonparametric tests was applied. Mann Whitney U test, Spearman's brho test and Kruskal Wallis test were used in the study. The Personal Information Form (KBF) was prepared by researchers within the scope of the research, the Conscious Awareness Scale was developed by Brown and Ryan [15], and Hart et al. [4] developed the Social Appearance Anxiety Scale (SSI). Considering these results, non-parametric analyses were utilized in the present study. The data were analyzed by SPSS 20.00 package program.

\section{Findings}

Table 1. Shapiro-Wilk Normality Test Results

\begin{tabular}{cccc}
\hline & \multicolumn{3}{c}{ Shapiro-Wilk } \\
& Statistic & $\boldsymbol{d} \boldsymbol{f}$ & $\boldsymbol{p}$ \\
\hline S.A.A. &, 945 & 295 &, 000 \\
Awareness &, 974 & 295 &, 000 \\
\hline
\end{tabular}

It has been determined that distributions are not normally distributed as a result of the Shapiro-Wilk test to determine whether the Social Appearance Anxiety and Conscious Awareness distributions have a parametric distribution.

The results of the Mann Whitney U test to determine whether the Teacher candidates' Social Appearance Anxiety and Conscious Awareness levels significantly differed according to the gender variable appear to have no significant difference between the averages.

The results of the Mann Whitney U test to determine whether the Teacher candidates' Social Appearance Anxiety and Conscious Awareness levels significantly differed according to the Parent Coincidence status variable showed no significant difference between the averages.

The results of the Kruskal Wallis test to determine whether the Teacher Candidates' Social Appearance Anxiety and Conscious Awareness levels significantly differed according to the age variable were found to be significantly different in the Conscious Awareness variable between the averages. When the Mann Whitney U test was performed for the different source, the Conscious Awareness variable was found to be significantly different in favor of younger ages 1-4, 2-4, 3-4.

Table 2. Mann whitney U Test Results on Gender Variable

\begin{tabular}{ccccccc}
\hline & Gender & $\mathbf{n}$ & Order Average & Rank Sum & U & p \\
\hline S. A. A. & Male & 109 & 139,14 & 15166,50 & 9171,5 & 0,172 \\
& Female & 186 & 153,19 & 28493,50 & & 0,387 \\
Cognitive & Male & 109 & 142,39 & 15520,50 & 9525,5 & \\
Awareness & Female & 186 & 151,29 & 28139,50 & & \\
\hline
\end{tabular}

Table 3. Mann Whitney U Test Results on Parent-Child Situations

\begin{tabular}{ccccccc}
\hline & P. A. S. & n & Order Average & Rank Sum & U & p \\
\hline \multirow{2}{*}{ S.A. A. } & Yes & 214 & 148,51 & 42027,50 & 1554,500 & 0,620 \\
& No & 81 & 136,04 & 1632,50 & &, 647 \\
Cognitive & Yes & 214 & 147,53 & 41751,50 & 1565,500 & \\
Awareness & No & 81 & 159,04 & 1908,50 & & \\
\hline
\end{tabular}

Table 4. Kruskal Wallis Test Results for Age Variable

\begin{tabular}{lccccccc}
\hline & Age & $\mathbf{n}$ & Order Average & $\boldsymbol{d f}$ & $\mathbf{X}^{\mathbf{2}}$ & $\mathbf{p}$ & No Significant Difference \\
\hline & 1 & 106 & 157,86 & 3 & 5,803 &, 122 & \\
S.A.A. & 2 & 102 & 144,43 & & & & \\
& 3 & 58 & 144,24 & & & & \\
& 4 & 29 & 71,20 & & & & \\
Cognitive & 1 & 106 & 137,96 & 3 & 9,401 &, 024 & \\
Awareness & 2 & 102 & 156,85 & & & & $1-4,2-4,3-4$ There is a \\
& 3 & 58 & 152,40 & & & & significant difference between \\
& 4 & 29 & 53,70 & & & & \\
\hline
\end{tabular}


Table 5. Kruskal Wallis Test Results for Class Level Variable

\begin{tabular}{cccccccc}
\hline & Class level & $\mathbf{n}$ & Order Average & $\boldsymbol{d} \boldsymbol{f}$ & $\mathbf{X}^{\mathbf{2}}$ & $\mathbf{p}$ & No Significant Difference \\
\hline & 1 & 64 & 136,23 & 3 & 3,769 &, 288 & \\
S.A.A. & 2 & 156 & 152,28 & & & & \\
& 3 & 44 & 161,23 & & & & \\
& 4 & 31 & 131,97 & & & & \\
Cognitive & 1 & 64 & 133,73 & 3 & 12,065 &, 007 & \\
Awareness & 2 & 156 & 163,21 & & & & \\
& 3 & 44 & 138,34 & & & & \\
\hline
\end{tabular}

Kruskal Wallis test to determine whether teachers 'candidates' social appearance anxiety and conscious awareness levels significantly differed according to class level variable appear to have no significant difference between the averages.

Table 6. Spearman's Rho Test of Social Appearance Anxiety and Awareness Levels

\begin{tabular}{cccc}
\hline & & S.A.C. & C.A. \\
\hline & Pearson Correlation & 1 & $-248^{* *}$ \\
S. A .A. & Sig.(2-tailed) & &, 000 \\
& $\mathrm{n}$ & 295 & \\
\hline \multirow{2}{*}{ Cognitive } & Pearson Correlation & $-248^{* *}$ & 1 \\
Awareness & Sig.(2-tailed) &, 000 & \\
& $\mathrm{n}$ & 295 & 295 \\
\hline
\end{tabular}

It has been found that there is a negative correlation between Spearman's brho test Social Appearance Anxiety and Conscious Awareness levels for the relationship between Teacher candidates' Social Appearance Anxiety and Conscious Awareness levels.

\section{Conclusions and Discussion}

It seems that there is no meaningful difference between the mean of the teachers' candidates according to the gender variable of Social Appearance Anxiety and Conscious Awareness levels. It is observed that there is no significant difference between the mean of the Teacher candidates' Social Appearance Anxiety Level and Conscious Awareness Levels according to the Parent Share Status variables.

It was found that there was a meaningful difference in the Conscious Awareness variable between the averages according to the age variable of the Teacher candidates' of Social Anxiety Appearance and Conscious Awareness levels. The Conscious Awareness variable was found to be significantly different for small ages 1-4, 2-4, 3-4.

It is seen that there is no meaningful difference between the mean of the teachers' candidates according to the class level variable of Social Appearance Anxiety and Conscious Awareness levels.
It has been determined that there are no significant differences between Conscious Awareness and social anxiety in the context of gender change. There were also studies [23] in which there were differences in social appearance anxiety levels according to gender variable, besides the studies that determined that there was no meaningful difference between social anxiety and gender change in screening of the constructed article [24]. Therefore, it can be said that the results of the research support the literature.

It has been determined that in the context of age change, individuals differ significantly in the level of Social Appearance Anxiety and Conscious Awareness Levels. In the review of the literature on the field, there is no study related to social anxiety and conscious awareness levels were assessed in terms of age. So there is no data accumulation which can directly compare research results. However, it was found that gender roles were significantly related to the Social Appearance Anxiety Levels in the context of Social Appearance Anxiety and gender roles studies $[25,24,23]$ and Conscious Awareness and the age context, it is not meaningful [26] and there are meaningful interactions [27]. Therefore, it can be said that the work carried out supports the results of the literature.

There could not be found any study examined the relationship between of Social Appearance anxiety and Conscious Awareness. Therefore, there is not any data accumulation which can directly compare the results of the research. However, due to the examination of the field literature, it is thought that social appearance anxiety can be said to be a derivation of social appearance and social appearance is a psychopathological situation such as depression, OCD, etc., so that conscious awareness and neurotic tendencies are examined. In studies examining conscious awareness and neurotic tendencies, it has been determined that there is a significant negative relationship between conscious awareness and neurotic tendencies [28, 29]. It can be said that the results obtained without the study support the results of the literature when considering the meaningful relationships between negative awareness and social anxiety which is considered as a neurotic tendency in the study carried out. 


\section{REFERENCES}

[1] Keklik, B. (2016). Öğretim üyelerinin dış görünüşlerinin ögrenciler tarafindan algılanma biçiminin incelenmesine yönelik bir araştırma. Uluslararası Alanya İşletme Fakültesi Dergisi, 4(3), 129-141.

[2] Van den Elzeni, M. E. P., Versnel, S. L., Hovius, S. E. R., Passchier, J., Duivenvoorden, H. J. and Mathijssen, I. M. J. (2012). Adults with congenital or acquired facial disfigurement: Impact of appearance on social functioning. Journal of Cranio-Maxillofacial Surgery, 40(8), 777-782.

[3] Levinson, C. A., Rodebaugh, T. L., White, E.K., Menatti, A. R., Weeks, J. W., Iacovino, J. M. and Warren, C. S. (2013). Social appearance anxiety, perfectionism, and fear of negative evaluation. Distinct or shared risk factors for social anxiety and eating disorders? Original Research Article Appetite, 67(1), 125-133.

[4] Hart, T. A., Flora, D. B., Palyo, S. A., Fresco, D. M., Holle, C. and Heimberg, R. C. (2008). Development and Examination of the Social Appearance Anxiety Scale. Assessment, 15, 48-59.

[5] Hart, E. A., Leary, M. R. and Rejeski, W. J. (1989). The measurement of social physique anxiety. Journal of Sport and Exercise Psychology, 11, 94-104.

[6] Claes, L., Hart, T. A., Smits, D., Van Den Eynde, F., Mueller, A. and Mitchell, J. E. (2012). Validation of the social appearance anxiety scale in female eating disorder patients. European Eating Disorders Review, 20(5), 406-409.

[7] Doğan, T. (2009). Bilinçli ve kendini değerlendirme süreçlerinin sosyal anksiyete açısından incelenmesi. Doktora Tezi, Sakarya Üniversitesi Sosyal Bilimler Enstitüsü, Sakarya.

[8] Doğan, U. and Çolak, T. S. (2016). Self-concealment, social network sites usage, social appearance anxiety, loneliness of high school students: A Model Testing. Journal of Education and Training Studies, 4(6), 176-183.

[9] Irmak, H.S. (2015). Güç artık internette. Addicta: The Turkish Journal on Addictions, 2,149-153.

[10] Özsoy, G. (2008). Üstbiliş. Türk Eğitim Bilimleri Dergisi. 6(4), 713-740.

[11] Rickey, D. and Stacy, A. M. (2000). The role of metacognition in learning chemistry. Journal of Chemical Education, 77(7), 915-920.

[12] Kabat-Zinn, J. (2003). Mindfulness-based interventions in context: past, present, and future. Clinical Psychology: Science and Practice, 10, 144-156.

[13] Kabat-Zinn, J. (2005). Full Catastrophe Living: Using the Wisdom of Your Body and Mind to Face Stress, Pain, and Illness. New York: Bantam Dell.

[14] Fletcher, L. B., Schoendorff, B. and Hayes, S. C. (2010) Searching for mindfulness in the brain: A process-oriented approach to examining the neural correlates of mindfulness. Mindfulness, 1, 41-63.

[15] Brown, K. M. and Ryan, R. M. (2003). The benefits of being present: Mindfulness and its role in psychological well-being. Journal of Personality and Social Psychology, 84(4), 822- 848.

[16] Wilson, T. D. (2002). Strangers to ourselves: Discovering the adaptive unconscious. Cambridge, MA: Harvard University Press.

[17] Zvolensky, M. J., Bonn-Miller, M. O., Bernstein, A., McLeish, A. C., Feldner, M. T. and Leen-Feldner, E.W. (2006). Anxiety sensitivity interacts with marijuana use in the prediction of anxiety symptoms and panic-related catastrophic thinking among daily tobacco users. Behaviour Research and Therapy, 44, 907-924.

[18] Schonert-Reichl, K. A. and Lawlor, M. S. (2010). The effects of a mindfulness-based education program on pre-and early adolescents' well-being and social and emotional competence. Mindfulness, 1(3), 137-151.

[19] Kocovski, N.L., Fleming, E., Hawley, L.L., Ho, M.H.R. and Antony, M.M. (2015). Mindfulness and acceptance-based group therapy and traditional cognitive behavioral group therapy for social anxiety disorder: Mechanisms of change. Behaviour Research and Therapy, 70, 11-22.

[20] Arlı, M. and Nazik, H. (2001). Bilimsel araştırmaya giriş. Ankara: Gazi Kitabevi

[21] Doğan, T. (2010). Sosyal görünüş kaygısı ölçeğinin Türkçe uyarlaması, geçerlik ve güvenirlik çalışması. Hacettepe Üniversitesi Eğitim Fakültesi Dergisi, 39, 151-59.

[22] Büyüköztürk, Ş. (2014). Sosyal Bilimler İçin Veri Analizi El Kitabl, 20. Baskl. Ankara: Pegem Akademi Yayınc1lı.

[23] Alemdağ S., Öncü E. (2015). The inandstigation of participation physical activity and social appearance anxiety at the preservice teachers. International Journal of Science Culture and Sport, 11, 287-300.

[24] Çınar, H. and Keskin, N. (2015). Öğrencilerin sosyal görünüş kaygısının öğrenim yeri tercihlerine etkisi. Electronic Journal of Vocational Colleges. 14. BÜROKON Özel Sayısi: 457-46.

[25] Y1lmaz, N. (2015). Obez bireylerde benlik saygisı, sosyal görünüş kaygısı ve vücut algısı. Uzmanlık Tezi Dokuz Eylül Üniversitesi Tıp Fakültesi Aile Hekimliği Anabilim Dalı, İzmir .

[26] Cengiz, R., Serdar, E. and Donuk, B. (2016). Üniversite öğrencilerinin bilinçli farkındalı ve girişimcilik düzeylerinin incelenmesi. International Journal of Social Sciences and Education Research, 2, 1632-1643.

[27] Özyeşil, Z., Aslan, C., Kesici, Ş. and Deniz, M. E. (2011). Bilinçli farkındalık ölçeği' nin Türkçeye uyarlama çalışması. Eğitim ve Bilim, 36(160), 224-235.

[28] Raphiphatthana, B., Jose, P. E. and Kielpikowski, M. (2016). How do the facets of mindfulness predict the constructs of depression and anxiety as seen through the lens of the tripartite theory? Personality and Individual Differences, 93, 104-111.

[29] Armstrong, L. A. and Rimes, K. A. (2016). Mindfulness-based cognitive therapy for neuroticism (stress vulnerability): A pilot randomized study. Behavior Therapy 47(3), 287-298. 